\title{
A pilot study of peptide vaccines for VEGF receptor 1 and 2 in patients with recurrent/progressive high grade glioma
}

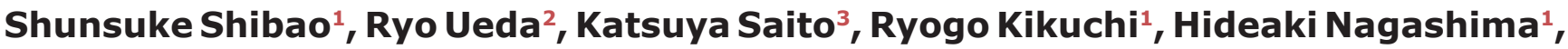 \\ Atsuhiro Kojima ${ }^{4}$, Hiroshi Kagami ${ }^{5}$, Eriel Sandika Pareira ${ }^{1}$, Hikaru Sasaki ${ }^{1}$, Shinobu \\ Noji $^{6}$, Yutaka Kawakami ${ }^{6}$, Kazunari Yoshida ${ }^{1}$ and Masahiro Toda ${ }^{1}$

\footnotetext{
${ }^{1}$ Department of Neurosurgery, Keio University School of Medicine, Shinjuku-ku, Tokyo 160-8582, Japan

${ }^{2}$ Department of Neurosurgery, Kawasaki Municipal Hospital, Kawasaki, Kawasaki-ku, Kawasaki, Kanagawa 210-0013, Japan

${ }^{3}$ Department of Neurosurgery, Ashikaga Red Cross Hospital, Ashikaga, Tochigi 326-0843, Japan

${ }^{4}$ Department of Neurosurgery, Saitama Municipal Hospital, Midori-ku, Saitama, Saitama 336-8522, Japan

${ }^{5}$ Department of Neurosurgery, Saiseikai Yokohamashi Tobu Hospital, Tsurumi-ku, Yokohama, Kanagawa 230-8765, Japan

${ }^{6}$ Division of Cellular Signaling, Institute for Advanced Medical Research, Keio University School of Medicine, Shinjuku-ku, Tokyo 160-8582, Japan
}

Correspondence to: Masahiro Toda, email: todam@keio.jp

Keywords: high grade glioma; peptide vaccine; vascular endothelial growth factor receptor

Received: August 08, $2017 \quad$ Accepted: March 13, $2018 \quad$ Published: April 20, 2018

Copyright: Shibao et al. This is an open-access article distributed under the terms of the Creative Commons Attribution License 3.0 (CC BY 3.0), which permits unrestricted use, distribution, and reproduction in any medium, provided the original author and source are credited.

\section{ABSTRACT}

Object: Early-phase clinical studies of glioma vaccines have shown feasibility and encouraging preliminary clinical activity. A vaccine that targets tumor angiogenesis factors in glioma microenvironment has not been reported. Therefore, we performed a pilot study to evaluate the safety and immunogenicity of a novel vaccination targeting tumor angiogenesis with synthetic peptides for vascular endothelial growth factor (VEGF) receptor epitopes in patients with recurrent/progressive high grade gliomas.

Methods: Eight patients received intranodal vaccinations weekly at a dose of $2 \mathrm{mg} / \mathrm{kg}$ bodyweight 8 times. T-lymphocyte responses against VEGF receptor (VEGFR) epitopes were assessed by enzyme linked immunosorbent spot assays.

Results: This treatment was well-tolerated in patients. The first four vaccines induced positive immune responses against at least one of the targeted VEGFR epitopes in the peripheral blood mononuclear cells in $\mathbf{8 7 . 5 \%}$ of patients. The median overall survival time in all patients was $\mathbf{1 5 . 9}$ months. Two achieved progression-free status lasting at least 6 months. Two patients with recurrent GBM demonstrated stable disease. Plasma IL-8 level was negatively correlated with overall survival.

Conclusion: These data demonstrate the safety and immunogenicity of VEGFR peptide vaccines targeting tumor vasculatures in high grade gliomas.

\section{INTRODUCTION}

Despite the recent advances obtained by the introduction of chemoradiotherapy with temozolomide (TMZ), the overall outcome of patients with high grade gliomas, such as glioblastoma (GBM), anaplastic astrocytoma (AA), and anaplastic oligodendroglioma (AO), remains dismal [1]. Options are particularly limited for patients with recurrent disease, and novel treatments are needed.

Cancer immunotherapy has become an attractive therapeutic modality for cancer, and is regarded as the fourth modality of cancer treatment after surgery, radiotherapy and chemotherapy [2]. Early-phase studies of glioma peptide-based vaccines targeting tumor associated antigens that have the potential ability to induce tumor- 
Table 1: Characteristics of 8 enrolled patients

\begin{tabular}{|c|c|c|c|c|c|c|c|c|c|c|c|}
\hline $\begin{array}{l}\text { Case } \\
\text { No. }\end{array}$ & Age (yrs) & Sex & Dx & Op. & RT & $\begin{array}{c}\text { Chemo/ } \\
\text { other agent }\end{array}$ & $\begin{array}{c}\text { No. of } \\
\text { progression } \\
\text { episodes }\end{array}$ & $\begin{array}{l}\text { corticosteroid } \\
\text { dosing prior to } \\
\text { vaccination }\end{array}$ & PS & IDH1 & $\begin{array}{c}1 p / 19 q \\
\text { codeletion }\end{array}$ \\
\hline 1 & 75 & $\mathrm{~F}$ & GBM & 1 & $\begin{array}{c}\text { Con.(60Gy), } \\
\text { SRS(36Gy) }\end{array}$ & TMZ, Bev. & 2 & none & 2 & WT & - \\
\hline 2 & 58 & M & GBM & 1 & Con.(60Gy) & TMZ & 1 & $1 \mathrm{mg} /$ day & 1 & WT & - \\
\hline 3 & 41 & F & AA & 1 & $\begin{array}{l}\text { Con.(50Gy), } \\
\text { SRS(14.7Gy) }\end{array}$ & TMZ & 2 & $1 \mathrm{mg} /$ day & 2 & $\mathrm{R} 132 \mathrm{H}$ & - \\
\hline 4 & 62 & $\mathrm{~F}$ & GBM & 1 & IMRT(60Gy) & TMZ & 1 & none & 1 & WT & - \\
\hline 5 & 68 & M & $\mathrm{AO}$ & $\begin{array}{c}4 \text { (Biopsy } \\
\text { 2) }\end{array}$ & Con.(50Gy) & TMZ & 4 & none & 2 & $\mathrm{R} 132 \mathrm{H}$ & + \\
\hline 6 & 37 & $\mathrm{M}$ & AA & 3 & Con., SRS & $\begin{array}{c}\text { ACNU, PAV, } \\
\text { TMZ }\end{array}$ & 4 & none & 0 & WT & - \\
\hline 7 & 59 & M & GBM & 2 & Con.(60Gy) & TMZ, IFN & 1 & none & 1 & WT & - \\
\hline 8 & 62 & $\mathrm{M}$ & GBM & 1 & Con.(60Gy) & TMZ & 1 & none & 1 & WT & - \\
\hline
\end{tabular}

Abbreviations: AA, anaplastic astrocytoma; ACNU, nimustine hydrochloride; AO, anaplastic oligodendroglioma; Bev., bevacizumab; Chemo, chemotherapy; Con., conventional; DA, diffuse astrocytoma; Dx, diagnosis; GBM, glioblastoma; IFN, $\beta$-interferon; IMRT, Intensity modulated radiation therapy; OA, oligoastrocytoma; Op., operation; PAV, procarbazine/ACNU/vincristine; PS, performance status; RT, radiotherapy; SRS, stereotactic radiosurgery; TMZ, temozolomide.

specific T-cell responses have shown feasibility and encouraging preliminary clinical activity [3-13]. The ultimate success of glioma vaccines depends on the further refinement of strategies to target appropriate multiple glioma-associated antigens [14], and to reverse gliomainduced global immune-suppression through immune checkpoint blockade [15-17].

Anti-cancer therapeutic approaches that target the vascular endothelial growth factor (VEGF) or inhibit its receptors, VEGF-receptor (VEGFR) 1 and VEGFR2, have recently been developed [18-21]. VEGFR1 and VEGFR2 are induced in a tumor stage-dependent manner during glioma progression [22] and are exclusively expressed in tumor vascular endothelial cells [20,23] and glioma cells [24, 25], suggesting that VEGF-receptors are promising targets for tumor endothelial cell specific therapy for glioma patients. Indeed, clinical studies of VEGFR peptide vaccines for patients with advanced gastrointestinal cancers and renal cell cancer exhibited feasibility and encouraging clinical activity [26, 27]. However, no clinical studies of a vaccine therapy targeting tumor angiogenesis factors such as VEGFR in high grade glioma patients has been reported. Thus, this study is the first to evaluate a peptide-based vaccine targeting tumor vasculatures in high grade gliomas. The HLA-A2402-restricted epitopes for this therapy included two that had been previously identified and evaluated for safety and potent immunogenicity in cancer patients: a VEGFR1-derived peptide (VEGFR1-1084) [28] and a VEGFR2-derived peptide (VEGFR2-169) [29, 30]. We hypothesized that this regimen would prove to be safe, and induce potent anti-glioma endothelial cell immune responses.

\section{RESULTS}

\section{Demographics and clinical characteristics}

A total of 9 patients, who were found to be HLA-A*2402 positive by DNA typing of HLA genomic variations, were enrolled in this study. Eight of the 9 patients who received 8 or more vaccinations (at least 2 months) were evaluated for further analysis. The remaining one patient dropped out from this study due to disease progression and was excluded from further analysis. Table 1 shows the characteristics of eight enrolled patients.

\section{Toxicity}

No major toxicity was found in this study. During the vaccination therapy, all eight patients developed a reaction at the injection site and one patient developed an ulcer at the injection site (Grade 3). No delayed wound healing or gastrointestinal bleeding was found during the therapy. Other adverse events, such as arterial and venous thromboembolism, hypertension, and proteinuria, which were reported in the clinical study of bevacizumab, were not detected.

\section{$\mathrm{CD8}^{+} \mathrm{T}$-cell response}

Seven $(87.5 \%)$ of the eight patients who received more than eight injections ( $>2$ months) of the vaccination showed induced $\mathrm{CD} 8^{+} \mathrm{T}$-cell response against VEGFR1-1084, and one patient (12.5\%) showed induced CD8 ${ }^{+}$T-cell response against VEGFR2-169 (Table 2). One 
Table 2: Clinical results in 8 enrolled patients

\begin{tabular}{|c|c|c|c|c|c|c|c|c|c|c|}
\hline \multirow{2}{*}{$\begin{array}{l}\text { Case } \\
\text { No. }\end{array}$} & \multirow[t]{2}{*}{ DTH } & \multirow[t]{2}{*}{ Toxicity } & \multicolumn{2}{|c|}{$\mathrm{CD8}^{+} \mathrm{T}$-cell before vaccination } & \multicolumn{2}{|c|}{$\mathrm{CD8}^{+} \mathrm{T}$-cell after vaccination } & \multicolumn{2}{|c|}{$\mathrm{CD8}^{+} \mathrm{T}$-cell positive response } & \multirow[t]{2}{*}{ Response } & \multirow{2}{*}{$\begin{array}{c}\text { OS } \\
\text { (days) }\end{array}$} \\
\hline & & & VEGFR1 & VEGFR2 & VEGFR1 & VEGFR2 & VEGFR1 & VEGFR2 & & \\
\hline 1 & + & - & - & - & $1+$ & - & + & - & PD & 541 \\
\hline 2 & + & - & - & $1+$ & $3+$ & $1+$ & + & - & SD & 413 \\
\hline 3 & + & - & $1+$ & - & $3+$ & $3+$ & + & + & PD & 156 \\
\hline 4 & + & - & - & $1+$ & $2+$ & $1+$ & + & - & $\mathrm{PD}$ & 415 \\
\hline 5 & + & - & - & $1+$ & $3+$ & - & + & - & PD & 673 \\
\hline 6 & + & - & - & $1+$ & - & - & - & - & PD & 965 \\
\hline 7 & + & - & $1+$ & - & $3+$ & - & + & - & $\mathrm{SD}$ & 424 \\
\hline 8 & + & - & - & $1+$ & $3+$ & - & + & - & PD & 530 \\
\hline
\end{tabular}

Abbreviations: DTH, delayed-type hypersensitivity; OS, overall survival; PD, progressive disease; PR, partial response; SD, stable disease; VEGFR, vascular endothelial growth factor receptor; +, positive; -, negative.

patient showed induced response to both VEGFR1 and VEGFR2 peptides, and one patient showed no response to the vaccination. The representative data from the $\gamma$-interferon enzyme-linked immunospot T (ELISPOT) assay and CTL responses in Case 3 before and after four injections (one month) are shown in Figure 1.

\section{Clinical outcomes}

Patients received a mean of $11.5( \pm 3.46)$ peptide vaccinations.

Two patients achieved stable disease (SD) and six patients $(75 \%)$ revealed progressive disease (PD) at the end of eight vaccinations (Table 2).

At the time of analysis, one patient still had SD and was alive (2.7 years), and seven patients had died. The Kaplan-Meier curves for overall survival in all eight patients and five GBM patients are shown in Figure 2A and $2 \mathrm{~B}$, respectively. The median overall survival time (mOS) in all patients and GBM patients was 15.9 months and 14.1 months, respectively. One-year OS was $87.5 \%$ for all patients and $100 \%$ for GBM patients. There was no significant correlation between the overall survival and increase in VEGFR-specific CD8 ${ }^{+} \mathrm{T}$-cell frequencies in the Peripheral blood mononuclear cells (PBMCs) of patients after vaccination (Figure 3).

We classified patients into two groups according to TNF-a, IL-6 and IL-8 levels after four vaccinations. Although TNF-a and IL- 6 were not significantly related to OS, the patients with IL-8 levels lower than median $(2.81 \mathrm{pg} / \mathrm{ml})$ showed significantly longer OS than those with IL-8 levels higher than median $(\mathrm{p}=0.0114)$ (Figure 4).

\section{DISCUSSION}

To our knowledge, this is the first clinical evaluation of peptide-based vaccines targeting tumor angiogenesis factors in high grade glioma patients. Our findings demonstrated the safety and immunogenicity, as well as preliminary efficacy of this approach.

Clinical trials of peptide-based vaccine therapy using the same VEGFR-derived/ HLA-A2402-restricted epitopes have been conducted to assess safety, tolerability, and potential clinical activity in patients with advanced gastrointestinal cancers and renal cell cancer [26, 27]. In the present study, we treated high grade glioma patients with a dose of VEGFR peptide that was previously determined to be safe. Furthermore, adverse effects to vaccination were limited to local erythema at the injection sites of the vaccine, indicating the safety of the VEGFR peptide vaccines. Adverse events, such as bleeding, wound-healing complications, arterial and venous thromboembolism, hypertension, and proteinuria, which were reported in the clinical study of bevacizumab, were not detected in this study.

This study is the first to document in vivo induction of specific $\mathrm{CD}^{+}{ }^{+} \mathrm{T}$-cell responses against two epitopes derived from tumor angiogenesis factors, VEGFR1-1084 and VEGFR2-169, in high grade glioma patients. Positive immune responses against VEGFR1 and VEGFR2 in PBMCs were induced in $87.5 \%$ and $12.5 \%$ of patients, respectively, suggesting that the VEGFR1-derived epitope was immunogenic in advanced high grade glioma patients. We did not find a correlation between the overall survival and the increase in the frequency of VEGFR-specific CD ${ }^{+}$ T-cells among the PBMCs of patients after vaccination. While VEGFR2 is frequently expressed in the vasculature $(100 \%)$ and tumors $(33 \%)$ of the patients with GBM, VEGFR1 is expressed in the vasculature and tumors of only $20 \%$ of the patients with GBM [20]. The CTL response of the PBMCs of the patients prior to vaccination was $25 \%$ for VEGFR1 and $62.5 \%$ for VEGFR2 (Table 2). This CTL response might contribute to the appreciable OS. The same phenomenon was observed in the clinical study of Wilms tumor 1 peptide vaccination. Izumoto et al. reported that, after the vaccination, CTLs in the responders might change qualitatively, but not 
A

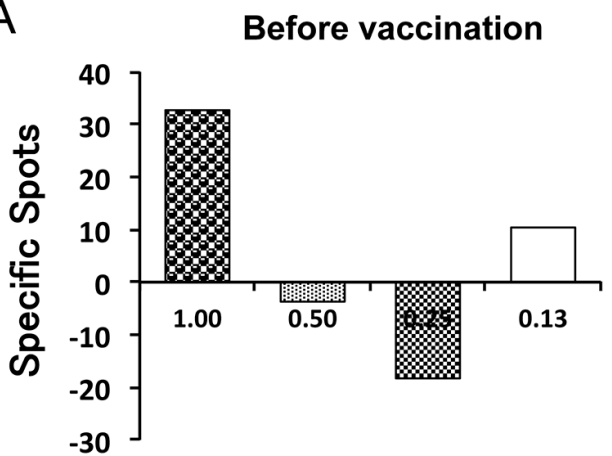

R/S ratio

B

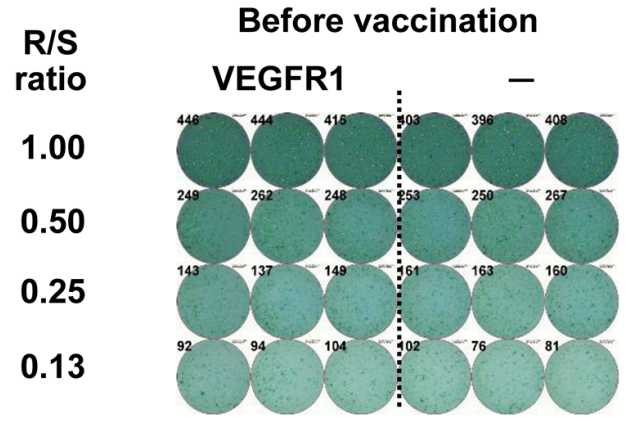

C

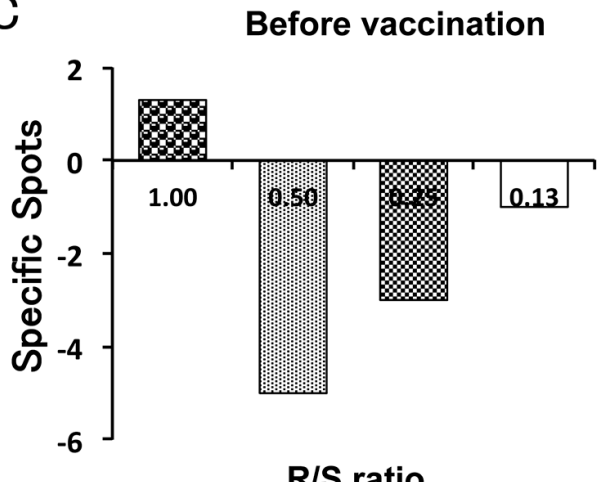

D

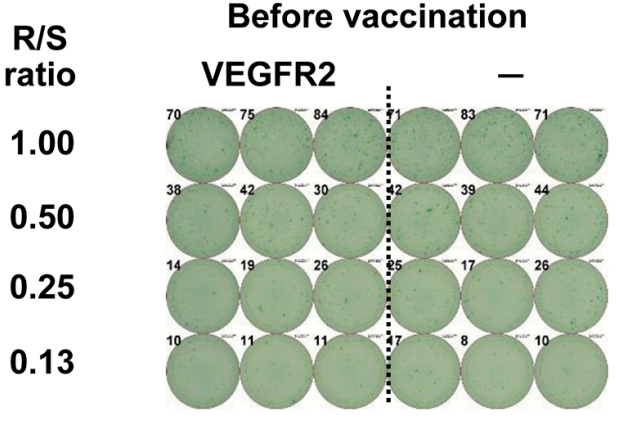

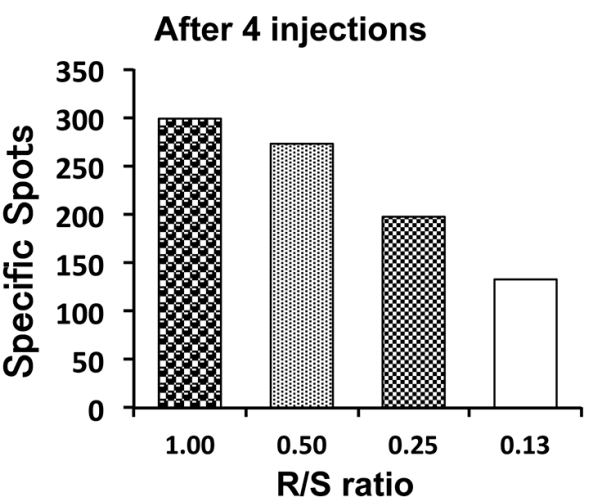

After 4 injections

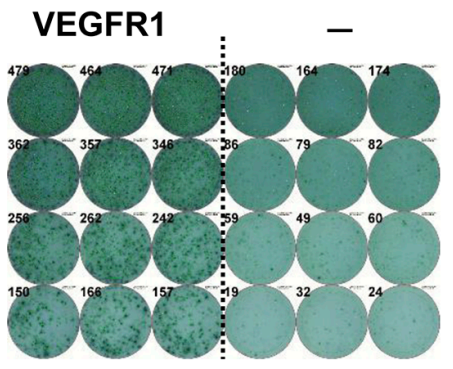

After 4 injections

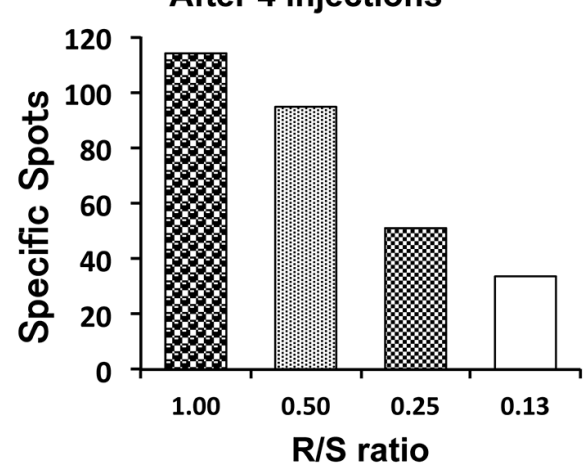

After 4 injections

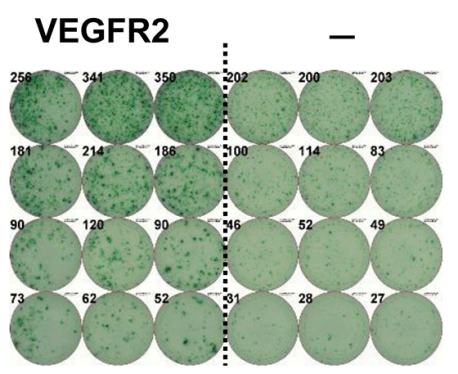

Figure 1: CD8 $^{+}$T-cell response. Enzymelinked immunospot $\mathrm{T}$ (ELISPOT) assay was performed to examine immunological response using peripheral blood mononuclear cells (PBMCs) that were collected after every four injections (one month). A $\gamma$-interferon ELISPOT assay was performed against vascular endothelial growth factor receptor (VEGFR) 1 (A and B) and VEGFR2 (C and D) peptide or HIV peptide control (-) (Case 3). Average number of specific spots in each R/S ratio (A and C) and representative ELISPOT assay (B and D) of the same patient are shown. R / S, responder / stimulator ratio. 
quantitatively [9]. Similarly, previous cancer immunotherapy trials have shown a poor correlation between clinical response and increase in antigen-specific $\mathrm{CD}^{+} \mathrm{T}$-cell frequencies [9, 31-34]. With regard to the lower immunogenicity of the VEGF2-derived epitope than that derived from VEGFR1, further studies are warranted to determine whether the VEGFR2-specific immune response can be induced more effectively in newly-diagnosed patients with glioma, with higher immunoresponsiveness, than immunosuppressed patients with recurrent high-grade glioma.
Based on our data showing a negative correlation between plasma IL-8 levels and overall survival, further studies are warranted to determine whether production of IL-8, which promotes progression of numerous malignancies, including high grade gliomas $[35,36]$, can be a surrogate measure of vaccine efficacy in future trials. Moreover, evaluation of other immunological biomarkers may lead to better understanding of the critical immune response indicators that may help to predict clinical responses.

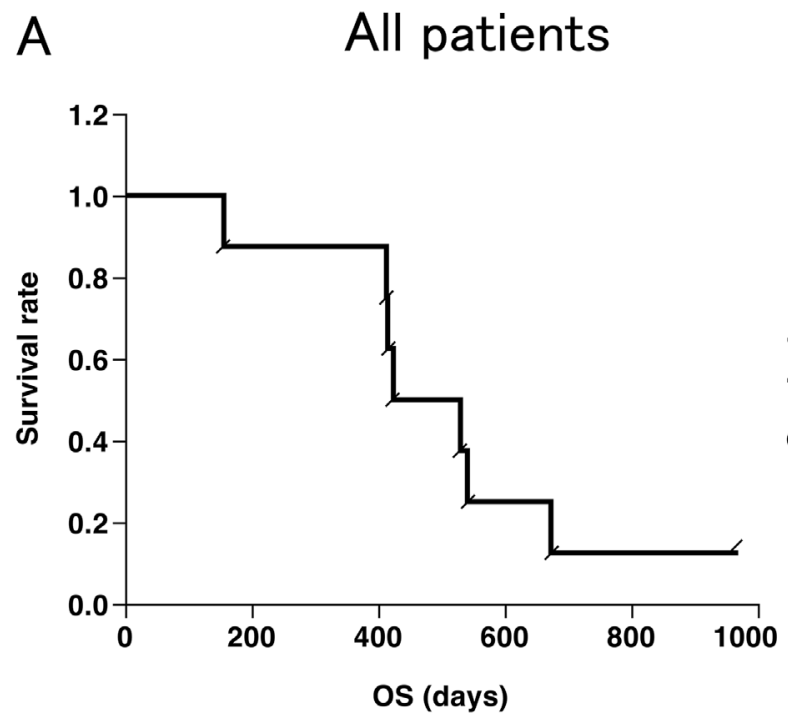

B $\quad$ GBM patients

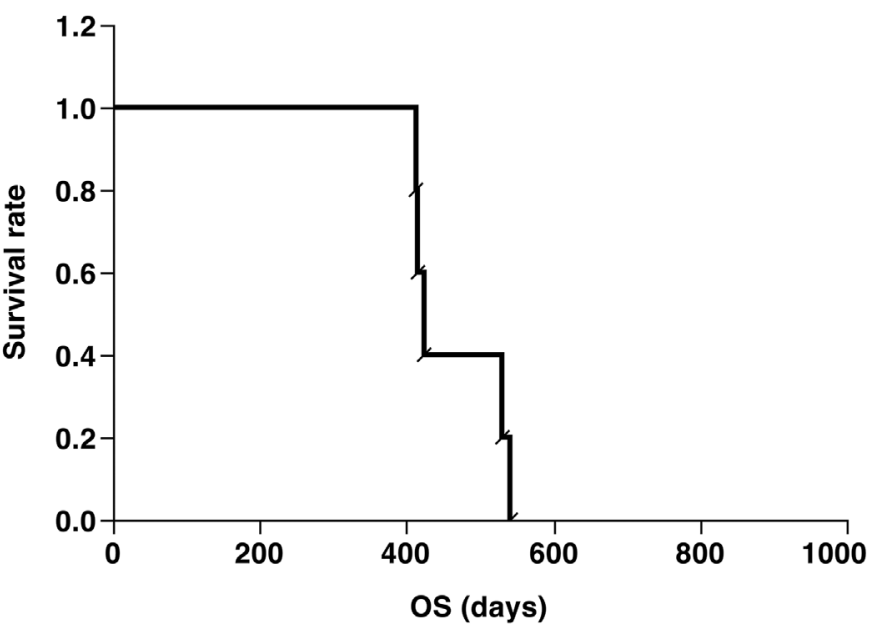

Figure 2: Kaplan-Meier curves. Overall survival (OS) of all patients ( $\mathrm{n}=8)(\mathbf{A})$ and GBM patients $(\mathrm{n}=5)(\mathrm{B})$, respectively. $(\mathbf{B})$ The median OS was 447 days (15.9 months) and 1-year OS was $87.5 \%$ in all patients. The median OS was 424 days (14.1 months) and 1-year OS was $100 \%$ in GBM patients.
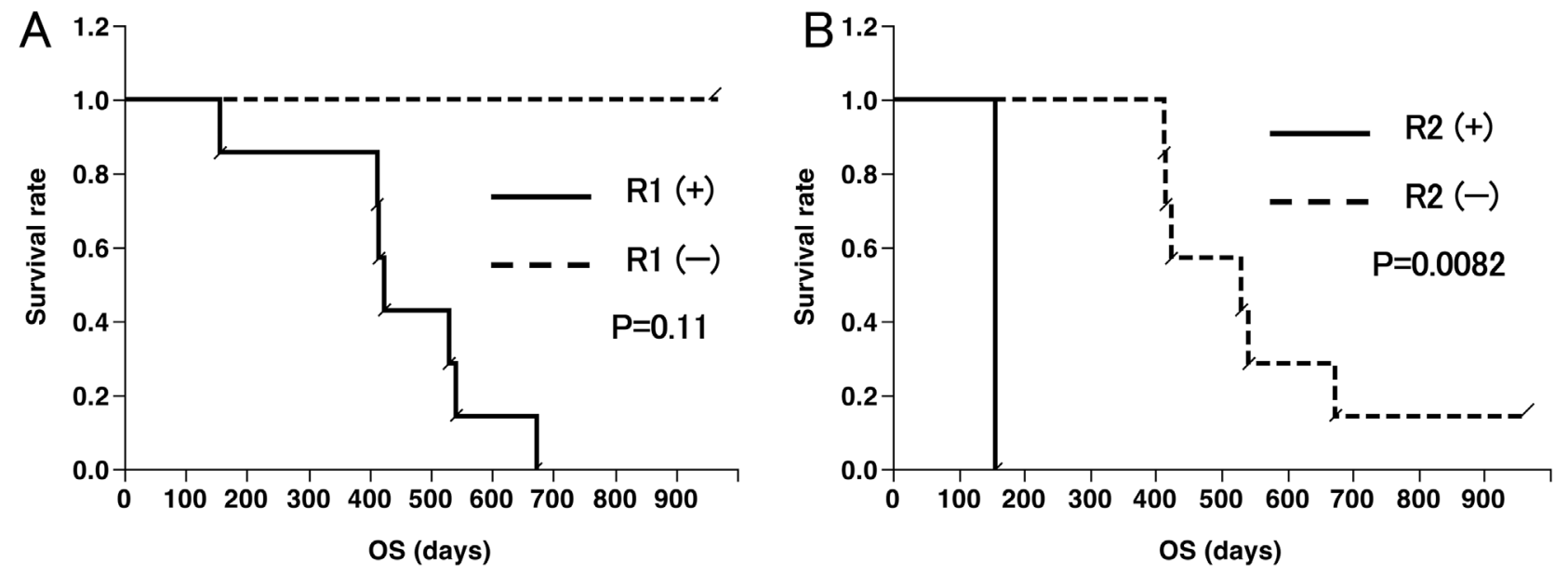

Figure 3: Overall survival (OS) curves according to $\mathbf{C D 8}^{+}$T-cell responses. (A) OS of eight patients with seven patients with positive $(+)$ and one patient with negative $(-)$ response to VEGFR1 peptide; (B) OS of eight patients with one patient with positive $(+)$ and seven patients with negative (-) response to VEGFR2 peptide. 
Recently, immunotherapy response assessment in neuro-oncology (iRANO) was reported to assess the clinical response of immunotherapy including vaccine therapy [37]. In iRANO, progressive disease is not confirmed for 6 months unless significant clinical decline unrelated to a comorbid event or concurrent medication is identified. In fact, one patient showed long SD in spite of PD at the end of eight injections (two months). Since progression confirmation is difficult in this protocol, we assessed the overall survival of patients to evaluate potential clinical activity of this therapy. In our study, the median overall survival from the initial vaccination in all patients and GBM patients was 15.9 months and 14.1 months, respectively. These results are comparable to those reported in the literature for previous clinical studies of glioma vaccines $[5,9,38]$ and various combination regimens of chemotherapy and/or radiotherapy for recurrent GBM patients, although the sample size was relatively small.

Agents targeting the VEGF/VEGF receptor axis in GBM have widely been tested [39]. However, recent phase III trials in newly-diagnosed GBM patients demonstrated a failure of the monoclonal anti-VEGFdirected antibody bevacizumab to extend overall survival when combined with chemotherapy and radiation therapy, despite benefits in progression-free survival and quality of life $[40,41]$. The studies in which bevacizumab was administered as monotherapy showed a median OS of 6.5-10.5 months [42-45], whereas our study showed median OS of 14.1 months in GBM. We cannot directly compare the results of the bevacizumab studies from those of our study due to many factors, such as variety of previous treatment, various histology, and different eligibility criteria. However, our VEGFR peptidebased vaccine may offer several advantages compared to bevacizumab therapy. First, although bevacizumab blocks only VEGF-A, however other members of the VEGF family, including VEGF-B to -E, help tumor angiogenesis. Our vaccine therapy against VEGFR1 and VEGFR2 may block the effects of VEGF-A to -E [46]. Second, VEGFR-specific $\mathrm{CD} 8^{+} \mathrm{T}$ cells induced by our peptide-based vaccine may be able to kill not only VEGFR-expressing glioma endothelial cells but also glioma cells, based on the evidence for the existence of tumoral VEGFR1/VEGFR2 expression [24, 25, 47]. Taken together, the combined application of VEGFR peptide-based vaccine and bevacizumab therapy may exhibit additive effects in clinical activity for high grade glioma patients.

This study has some limitations. Firstly, our study population was heterogenous, including both glioblastoma and other high-grade gliomas. Secondly, since the number of patients was small, the survival curves are only meant for reference. Thirdly, we included some confounding factors, such as molecular characteristics, time from diagnosis to treatment, and tumor mass.

In order to assess the safety, feasibility, and immunogenicity of the VEGFR peptide-based vaccine targeting tumor angiogenesis, we performed a pilot study for HLA-A2402 patients with recurrent/progressive high grade gliomas. The safety and the immunogenicity of this vaccine therapy have been verified, and the data suggest that VEGFR1/VEGFR2 vaccination may improve overall survival in this small population. However, definitive evidence of efficacy will require a future study of combination therapies with these vaccines, and standard treatment for newly-diagnosed high grade gliomas as an adjuvant setting, which is currently in the planning stages, as well as the immune-checkpoint blockade therapies.
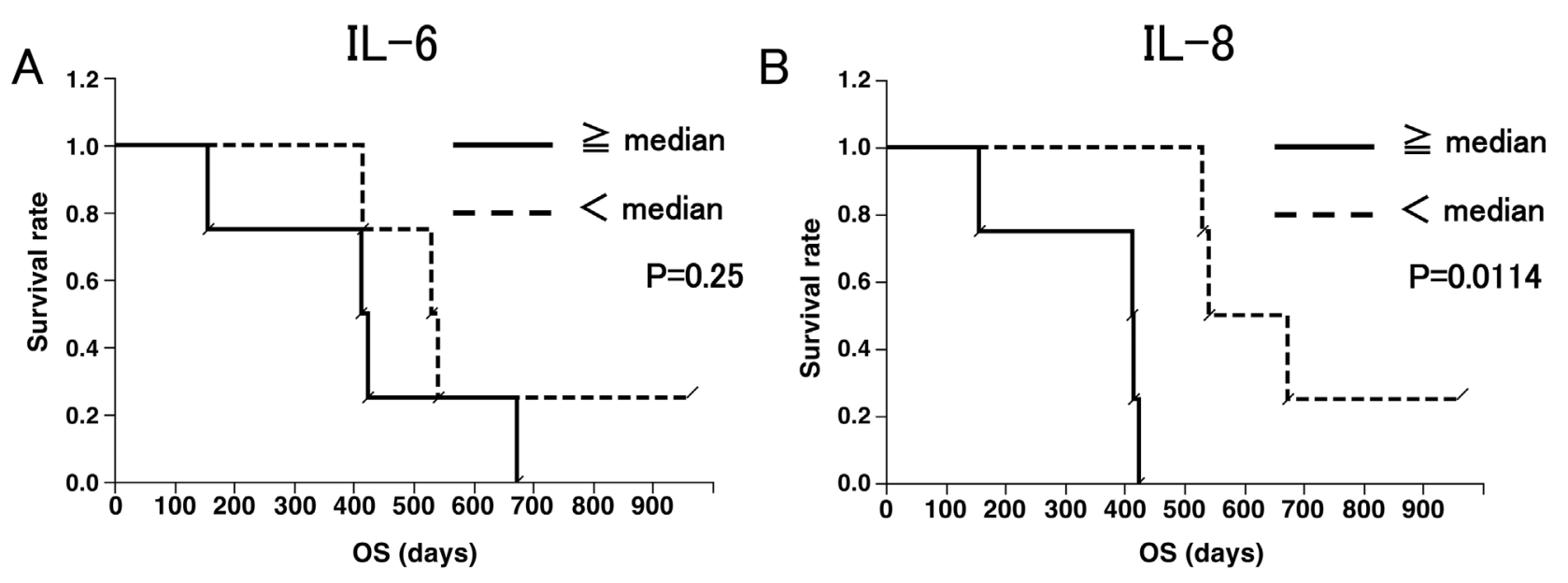

Figure 4: Overall survival (OS) curves according to IL-6 (A) and IL-8 (B) levels. (A) OS of eight patients, with four patients with IL-6 more than median $(0.505 \mathrm{pg} / \mathrm{ml})$ and four patients with IL-6 less than median. (B) OS of eight patients, with four patients with IL-8 more than median $(2.81 \mathrm{pg} / \mathrm{ml})$ and four patients with IL-8 less than median. IL-8 levels correlated with better survival. ( $\mathrm{p}=0.0114$; Wilcoxon test). 


\section{MATERIALS AND METHODS}

The study protocol was approved by the institutional ethics committee.

\section{Patient eligibility}

Patients diagnosed with high grade glioma including glioblastoma were enrolled in this study from May 2012 to August 2013 at Keio University Hospital (Tokyo, Japan).

Inclusion criteria were: 1) histological diagnosis of high grade glioma (WHO grade III or IV), 2) patients who had PD at study entry, 3) HLA genotyping; HLA-A*2402, 4) age between 16 and 80 years, 5) Eastern Cooperative Oncology (ECOG) performance status (PS) 0-2, 6) completion of standard treatment [surgical therapy (ST) + radiation therapy (RT) + temozolomide], 7) four-week interval from last chemotherapy or radiotherapy, 8) adequate bone-marrow, cardiac, pulmonary, hepatic and renal functions including neutrophil $\geq 1,000 / \mu 1$, platelet count $\geq 50,000 / \mu 1$, hemoglobin $\geq 8 \mathrm{~g} / \mathrm{dL}$, plasma aspartate aminotransferase and alanine aminotransferase levels $\leq 4$ times the normal limit, plasma bilirubin levels $\leq 1.5$ times the normal limit, plasma albumin levels $\geq 2.5 \mathrm{~g} / \mathrm{dL}$, plasma creatinine levels $\leq 2.0 \mathrm{mg} / \mathrm{dL}$, 9) life expectancy $>3$ months, 10) signature confirming informed consent.

Exclusion criteria were: 1) uncontrollable infection, 2) the presence of another serious disease such as uncontrolled diabetes, hepatic disorder, cardiac disease, hemorrhage/bleeding, 3) total parenteral nutrition, 4) multiple cancers, 5) Myelodysplastic syndrome (MDS), MDS/myeloproliferative disease (MPD), and MPD, 6) allogenic hematopoietic stem cell transplantation, 7) severe immunological disorders (autoimmune disease, immunosuppression), 8) anaphylaxis to synthetic peptides 9) concurrent treatment with steroids or immunosuppressive agents, 10) pregnant or breast-feeding women, 11) mental disorder, 12) unhealed wound, 13) decision of unsuitability by the principal investigator or the physician in charge.

\section{Design of the VEGFRI/II vaccine therapy}

This study was a non-randomized, open label clinical trial with VEGFR1-1084 and VEGFR2-169 vaccines for recurrent/progressive high grade glioma.

The primary end-points of this study were the safety of the peptide vaccination and the median OS time. The secondary end-points were immunological responses.

\section{Radiologic response monitoring and other clinical end points}

Tumor size was assessed at weeks 9, 17, 25, and 33, and every 3 months thereafter using magnetic resonance imaging (MRI) scans with contrast enhancement. Response was evaluated by the Response Evaluation
Criteria in Solid Tumors (RECIST) by gadolinium (Gd) -enhanced T1 weighted images on the basis of the appearance of the pretreatment MRI [48]. OS was defined by the interval from study entry to date of death. MRI scans were used to evaluate time to progression.

\section{Treatment protocol}

The dose of the peptide was determined to be $2 \mathrm{mg} /$ $\mathrm{kg}$ body weight based on a previous study [49]. Safety was verified by the study conducted for patients with advanced pancreatic cancer [49].

VEGFR1 (VEGFR1-A24-1084) and VEGFR2 (VEGFR2-A24-169) were emulsified in incomplete Freund's adjuvant (Montanide ISA-51VG; SEPPIC, Paris, France) and administered subcutaneously close to an axillary or inguinal lymph node 8 times weekly. Patients treated more than 8 times ( $>2$ months) were enrolled. Administration of peptide vaccines was continued even after 8 injections if the patients consented.

\section{Toxicity assessment}

Toxicity was assessed based on the common terminology criteria for adverse effects version 4.0 (CTCAE ver. 4.0). Toxicity was defined as a toxicity of grade 4 or greater.

\section{Peptides}

GMP-grade VEGF1-1084 (SYGVLLWEI) and VEGFR2-169 peptides (RFVPDGNRI) were synthesized by the American Peptide Company (Sunnyvale, CA, USA) according to a standard solid-phase synthesis method, and purified by reversed-phase high-performance liquid chromatography (HPLC). The purity (>90\%) and the identity of the peptides were determined by analytical HPLC and mass spectrometry analysis, respectively. The VEGFR peptides were provided by the Human Genome Center, The Institute of Medical Science, the University of Tokyo (Tokyo, Japan). The VEGF1-1084 and VEGFR2-169 peptides, and the epitope peptides derived from the HIV-Envelope protein restricted with HLA-A*2402 (RYLRDQQLL), were used for the measurement of $\mathrm{CD} 8^{+} \mathrm{T}$-cell responses.

\section{$\mathrm{CD8}^{+} \mathrm{T}$-cell responses to peptide stimulation}

To evaluate the specific $\mathrm{CD} 8^{+} \mathrm{T}$-cell response, an ELISPOT assay was performed following in vitro expansion. PBMCs were obtained from patients before the vaccination treatment and after every four injections (1 month), and then frozen and stored in liquid nitrogen until use. Frozen PBMCs derived from the same patient were thawed concurrently, and their viability was confirmed to be $>90 \%$. PBMCs $\left(5 \times 10^{5} / \mathrm{ml}\right)$ were cultured with $10 \mu \mathrm{g} / \mathrm{ml}$ of the respective peptide and $100 \mathrm{IU} / \mathrm{ml}$ of 
interleukin-2 (Novartis, Emeryville, CA) at $37^{\circ} \mathrm{C}$ with $5 \%$ $\mathrm{CO}_{2}$ for 2 weeks. The peptide was added to the culture at Day 0 and 7 (final concentration $10 \mu \mathrm{g} / \mathrm{ml}$ ). After incubation and CD4 depletion, harvested cells were used as responder cells in the ELISPOT assay, and peptidepulsed TISI cells were used as stimulator cells $\left(1 \times 10^{5}\right.$ cells per well). Non-peptide-pulsed TISI cells were used as negative control stimulator cells. Prepared harvested cells were cultured with peptide-pulsed TISI cells $(2 \times$ $10^{4}$ cells/well) at $1 / 1,1 / 2,1 / 4$, and $1 / 8$ ratio of responder cells and stimulator cells ( $\mathrm{R} / \mathrm{S}$ ratio) in a 96-well plate at $37^{\circ} \mathrm{C}$ overnight. Spots were captured and analyzed using an automated ELISPOT reader, ImmunoSPOT S4 or S5 (Cellular Technology Ltd, Cleveland, OH, USA) and ImmunoSpot Professional Software version 5.0.3 (Cellular Technology Ltd). The positivity of $\mathrm{CD}^{+} \mathrm{T}$-cell responses was identified when the average spot-forming cells per well in response to the respective peptide was $\geq 10$ spotforming cells per well in response to the control peptide. The degree of positivity was assessed as the follows: $1+$ : 10-199, 2+: 200-299, 3+: 300-. Positive response of the $\mathrm{CD}^{+} \mathrm{T}$-cells due to vaccination was defined as positivity increase after vaccination.

\section{Delayed-type hypersensitivity reaction}

To test the cell-mediated cytotoxicity response, we observed skin reaction at the injected site. A positive delayed-type hypersensitivity (DTH) skin test reaction was defined as greater than grade 1 induration based on CTCAE (ver. 4.0) after vaccination.

\section{Cytokine measurements}

Concentrations of TNF-a, IL-6 and IL-8 were measured in $25 \mu \mathrm{L}$ of EDTA plasma using an ultrasensitive electrochemiluminescence immunoassay, according to the manufacturer's instructions (Meso Scale Discovery: MSD; Rockville, MD). Ultrasensitive 10-plex plates were custom-designed for the Meso Scale Discovery 6000 instrument. Controls for standard curves were included in each plate. Samples with cytokine values less than the limit of detection were assigned a value of one half the limit of detection.

\section{Molecular-genetic analysis}

Chromosomal number aberrations (CNAs) were assessed by metaphase comparative genomic hybridization, as described previously $[50,51]$. Briefly, crude tumor DNA from formalin-fixed paraffin-embedded (FFPE) tissue was amplified by degenerate oligonucleotide primed-polymerase chain reaction (DOP-PCR), and labeled with another DOP-PCR, using digoxigenin (DIG)-11-dUTP (Roche, Mannheim, Germany). The reference DNA was amplified from $50 \mathrm{ng}$ of DNA from a healthy man or woman, and labeled with biotin-dUTP
(Roche). The probe mixture was denatured and hybridized to normal metaphase spreads (Vysis, Downers Grove, IL, USA). Unhybridized probes were washed out, and the metaphase spread was incubated with a fluorescein isothiocyanate-conjugated anti-DIG antibody (Roche) and rhodamine-conjugated avidin (Roche). Preparations were washed and counterstained with 4,6-diamino-2phenylinodole in antifade solution. Red, green, and blue images were acquired, and ratios of fluorescence intensity along chromosomes were quantitated using the CytoVision ${ }^{\circledR}$ Analysis System (Applied Imaging, San Jose, CA, USA).

Mutation of the IDH1 gene genes was assessed as follows: FFPE tissue sections were examined for IDH1 R132H using immunohistochemistry, with an anti-mutant IDH1 antibody (Dianova, Hamburg, Germany) [52].

\section{Statistical analysis}

All statistical analyses were performed with JMP 8.0.2 (SAS Institute, Cary, NC).

Statistical analyses were performed using the log-rank test. OS curves were estimated using KaplanMeier methodology. Differences were considered to be statistically significant when $\mathrm{p}<0.05$.

\section{Abbreviations}

AA: anaplastic astrocytoma, AO: anaplastic oligodendroglioma, CNA: chromosomal number aberration, CTCAE: common terminology criteria for adverse effects, DIG: digoxigenin, DOP-PCR: degenerate oligonucleotide primed-polymerase chain reaction, DTH: delayed-type hypersensitivity, ECOG: Eastern Cooperative Oncology, ELISPOT: enzymelinked immunospot T, FFPE: formalin-fixed paraffinembedded, GBM: glioblastoma, Gd: gadolinium, HPLC: high-performance liquid chromatography, iRANO: immunotherapy response assessment in neuro-oncology, mOS: median overall survival, MDS: myelodysplastic syndrome, MPD: myeloproliferative disease, MRI: magnetic resonance imaging, OS: overall survival, PBMC: peripheral blood mononuclear cell, PD: progressive disease, PS: performance status, RECIST: Response Evaluation Criteria in Solid Tumors, RT: radiation therapy, SD: stable disease, ST: surgical therapy, TMZ: temozolomide, VEGF: vascular endothelial growth factor, VEGFR: vascular endothelial growth factor receptor.

\section{Author contributions}

Conception and design: Shibao, Ueda, Toda. Acquisition of data: Shibao, Saito, Kikuchi, Kojima, Kagami, Sandika.

Analysis and interpretation of data: Shibao, Ueda, Toda.

Drafting the article: Shibao, Ueda, Toda. 
Critically revising the article: all authors.

Reviewed submitted version of manuscript: all authors.

Statistical analysis: Shibao.

Administrative/technical/material support: Noji.

Study supervision: Toda, Yoshida, Kawakami.

\section{ACKNOWLEDGMENTS}

We thank Ms. Tomoko Muraki and Ms. Naoko Aikawa for technical assistance and Department of Pharmacology at Keio University Hospital for vaccine preparation.

\section{CONFLICTS OF INTEREST}

The authors report no conflict of interest concerning the materials or methods used in this study or the findings specified in this paper.

\section{FUNDING/SUPPORT}

This work was supported by MEXT KAKENHI Grant Number JP 24659657 (Masahiro Toda).

\section{REFERENCES}

1. Stupp R, Mason WP, van den Bent MJ, Weller M, Fisher B, Taphoorn MJ, Belanger K, Brandes AA, Marosi C, Bogdahn U, Curschmann J, Janzer RC, Ludwin SK, et al. Radiotherapy plus concomitant and adjuvant temozolomide for glioblastoma. N Engl J Med. 2005; 352:987-96. https:// doi.org/10.1056/NEJMoa043330.

2. Kirkwood JM, Butterfield LH, Tarhini AA, Zarour H, Kalinski P, Ferrone S. Immunotherapy of cancer in 2012. CA Cancer J Clin. 2012; 62:309-35. https://doi. org/10.3322/caac.20132.

3. Schumacher T, Bunse L, Pusch S, Sahm F, Wiestler B, Quandt J, Menn O, Osswald M, Oezen I, Ott M, Keil $\mathrm{M}$, Balss J, Rauschenbach $\mathrm{K}$, et al. A vaccine targeting mutant IDH1 induces antitumour immunity. Nature. 2014; 512:324-7. https://doi.org/10.1038/nature13387.

4. Bloch O, Crane CA, Fuks Y, Kaur R, Aghi MK, Berger MS, Butowski NA, Chang SM, Clarke JL, McDermott MW, Prados MD, Sloan AE, Bruce JN, et al. Heat-shock protein peptide complex-96 vaccination for recurrent glioblastoma: a phase II, single-arm trial. Neuro Oncol. 2014; 16:274-9. https://doi.org/10.1093/neuonc/not203.

5. Okada H, Kalinski P, Ueda R, Hoji A, Kohanbash G, Donegan TE, Mintz AH, Engh JA, Bartlett DL, Brown CK, Zeh H, Holtzman MP, Reinhart TA, et al. Induction of CD8+ T-cell responses against novel glioma-associated antigen peptides and clinical activity by vaccinations with \{alpha\}-type 1 polarized dendritic cells and polyinosinic-polycytidylic acid stabilized by lysine and carboxymethylcellulose in patients with recurrent malignant glioma. J Clin Oncol. 2011; 29:330-6. https:// doi.org/10.1200/JCO.2010.30.7744.

6. Choi BD, Archer GE, Mitchell DA, Heimberger AB, McLendon RE, Bigner DD, Sampson JH. EGFRvIII-targeted vaccination therapy of malignant glioma. Brain Pathol. 2009; 19:713-23. https://doi. org/10.1111/j.1750-3639.2009.00318.x.

7. Terasaki M, Shibui S, Narita Y, Fujimaki T, Aoki T, Kajiwara K, Sawamura Y, Kurisu K, Mineta T, Yamada A, Itoh K. Phase I trial of a personalized peptide vaccine for patients positive for human leukocyte antigen--A24 with recurrent or progressive glioblastoma multiforme. J Clin Oncol. 2011; 29:337-44. https://doi.org/10.1200/ JCO.2010.29.7499.

8. Phuphanich S, Wheeler CJ, Rudnick JD, Mazer M, Wang $\mathrm{H}$, Nuno MA, Richardson JE, Fan X, Ji J, Chu RM, Bender JG, Hawkins ES, Patil CG, et al. Phase I trial of a multi-epitope-pulsed dendritic cell vaccine for patients with newly diagnosed glioblastoma. Cancer Immunol Immunother. 2013; 62:125-35. https://doi.org/10.1007/ s00262-012-1319-0.

9. Izumoto S, Tsuboi A, Oka Y, Suzuki T, Hashiba T, Kagawa N, Hashimoto N, Maruno M, Elisseeva OA, Shirakata T, Kawakami M, Oji Y, Nishida S, et al. Phase II clinical trial of Wilms tumor 1 peptide vaccination for patients with recurrent glioblastoma multiforme. J Neurosurg. 2008; 108:963-71. https://doi.org/10.3171/JNS/2008/108/5/0963.

10. Sampson JH, Archer GE, Mitchell DA, Heimberger AB, Herndon JE 2nd, Lally-Goss D, McGehee-Norman S, Paolino A, Reardon DA, Friedman AH, Friedman HS, Bigner DD. An epidermal growth factor receptor variant IIItargeted vaccine is safe and immunogenic in patients with glioblastoma multiforme. Mol Cancer Ther. 2009; 8:27739. https://doi.org/10.1158/1535-7163.MCT-09-0124.

11. Sampson JH, Heimberger AB, Archer GE, Aldape KD, Friedman AH, Friedman HS, Gilbert MR, Herndon JE 2nd, McLendon RE, Mitchell DA, Reardon DA, Sawaya $\mathrm{R}$, Schmittling RJ, et al. Immunologic escape after prolonged progression-free survival with epidermal growth factor receptor variant III peptide vaccination in patients with newly diagnosed glioblastoma. J Clin Oncol. 2010; 28:4722-9. https://doi.org/10.1200/JCO.2010.28.6963.

12. Sampson JH, Aldape KD, Archer GE, Coan A, Desjardins A, Friedman AH, Friedman HS, Gilbert MR, Herndon JE, McLendon RE, Mitchell DA, Reardon DA, Sawaya R, et al. Greater chemotherapy-induced lymphopenia enhances tumor-specific immune responses that eliminate EGFRvIIIexpressing tumor cells in patients with glioblastoma. Neuro Oncol. 2011; 13:324-33. https://doi.org/10.1093/neuonc/ noq 157.

13. Schuster J, Lai RK, Recht LD, Reardon DA, Paleologos NA, Groves MD, Mrugala MM, Jensen R, Baehring JM, Sloan A, Archer GE, Bigner DD, Cruickshank S, et al. A phase II, multicenter trial of rindopepimut (CDX-110) in 
newly diagnosed glioblastoma: the ACT III study. Neuro Oncol. 2015; 17:854-61. https://doi.org/10.1093/neuonc/ nou348.

14. Neagu MR, Reardon DA. An Update on the Role of Immunotherapy and Vaccine Strategies for Primary Brain Tumors. Curr Treat Options Oncol. 2015; 16:54. https://doi. org/10.1007/s11864-015-0371-3.

15. Hodi FS, O'Day SJ, McDermott DF, Weber RW, Sosman JA, Haanen JB, Gonzalez R, Robert C, Schadendorf D, Hassel JC, Akerley W, van den Eertwegh AJ, Lutzky J, et al. Improved survival with ipilimumab in patients with metastatic melanoma. N Engl J Med. 2010; 363:711-23. https://doi.org/10.1056/NEJMoa1003466.

16. Topalian SL, Hodi FS, Brahmer JR, Gettinger SN, Smith DC, McDermott DF, Powderly JD, Carvajal RD, Sosman JA, Atkins MB, Leming PD, Spigel DR, Antonia SJ, et al. Safety, activity, and immune correlates of anti-PD-1 antibody in cancer. N Engl J Med. 2012; 366:2443-54. https://doi.org/10.1056/NEJMoa1200690.

17. Wolchok JD, Kluger H, Callahan MK, Postow MA, Rizvi NA, Lesokhin AM, Segal NH, Ariyan CE, Gordon RA, Reed K, Burke MM, Caldwell A, Kronenberg SA, et al. Nivolumab plus ipilimumab in advanced melanoma. N Engl J Med. 2013; 369:122-33. https://doi.org/10.1056/ NEJMoa1302369.

18. Desjardins A, Reardon DA, Herndon JE 2nd, Marcello J, Quinn JA, Rich JN, Sathornsumetee S, Gururangan S, Sampson J, Bailey L, Bigner DD, Friedman AH, Friedman $\mathrm{HS}$, et al. Bevacizumab plus irinotecan in recurrent WHO grade 3 malignant gliomas. Clin Cancer Res. 2008; 14:7068-73. https://doi.org/10.1158/1078-0432. CCR-08-0260.

19. Vredenburgh JJ, Desjardins A, Herndon JE 2nd, Marcello J, Reardon DA, Quinn JA, Rich JN, Sathornsumetee S, Gururangan S, Sampson J, Wagner M, Bailey L, Bigner DD, et al. Bevacizumab plus irinotecan in recurrent glioblastoma multiforme. J Clin Oncol. 2007; 25:4722-9. https://doi. org/10.1200/JCO.2007.12.2440.

20. Batchelor TT, Sorensen AG, di Tomaso E, Zhang WT, Duda DG, Cohen KS, Kozak KR, Cahill DP, Chen PJ, Zhu M, Ancukiewicz M, Mrugala MM, Plotkin S, et al. AZD2171, a pan-VEGF receptor tyrosine kinase inhibitor, normalizes tumor vasculature and alleviates edema in glioblastoma patients. Cancer Cell. 2007; 11:83-95. https:// doi.org/10.1016/j.ccr.2006.11.021.

21. Brandes AA, Stupp R, Hau P, Lacombe D, Gorlia T, Tosoni A, Mirimanoff RO, Kros JM, van den Bent MJ. EORTC study 26041-22041: phase I/II study on concomitant and adjuvant temozolomide (TMZ) and radiotherapy (RT) with PTK787/ZK222584 (PTK/ZK) in newly diagnosed glioblastoma. Eur J Cancer. 2010; 46:348-54. https://doi. org/10.1016/j.ejca.2009.10.029.

22. Millauer B, Shawver LK, Plate KH, Risau W, Ullrich A. Glioblastoma growth inhibited in vivo by a dominant-negative Flk-1 mutant. Nature. 1994; 367:576-9. https://doi.org/10.1038/367576a0.

23. Hatva E, Kaipainen A, Mentula P, Jaaskelainen J, Paetau A, Haltia M, Alitalo K. Expression of endothelial cell-specific receptor tyrosine kinases and growth factors in human brain tumors. Am J Pathol. 1995; 146:368-78.

24. Kessler T, Sahm F, Blaes J, Osswald M, Rubmann P, Milford D, Urban S, Jestaedt L, Heiland S, Bendszus M, Hertenstein A, Pfenning PN, Ruiz de Almodovar C, et al. Glioma cell VEGFR-2 confers resistance to chemotherapeutic and antiangiogenic treatments in PTEN-deficient glioblastoma. Oncotarget. 2015; 6:31050-68. https://doi.org/10.18632/ oncotarget.2910.

25. Lu KV, Chang JP, Parachoniak CA, Pandika MM, Aghi MK, Meyronet D, Isachenko N, Fouse SD, Phillips JJ, Cheresh DA, Park M, Bergers G. VEGF inhibits tumor cell invasion and mesenchymal transition through a MET/ VEGFR2 complex. Cancer Cell. 2012; 22:21-35. https:// doi.org/10.1016/j.ccr.2012.05.037.

26. Masuzawa T, Fujiwara Y, Okada K, Nakamura A, Takiguchi S, Nakajima K, Miyata H, Yamasaki M, Kurokawa Y, Osawa R, Takeda K, Yoshida K, Tsunoda T, et al. Phase I/II study of S-1 plus cisplatin combined with peptide vaccines for human vascular endothelial growth factor receptor 1 and 2 in patients with advanced gastric cancer. Int J Oncol. 2012; 41:1297-304. https://doi.org/10.3892/ijo.2012.1573.

27. Yoshimura K, Minami T, Nozawa M, Uemura H. Phase I clinical trial of human vascular endothelial growth factor receptor 1 peptide vaccines for patients with metastatic renal cell carcinoma. Br J Cancer. 2013; 108:1260-6. https://doi.org/10.1038/bjc.2013.90.

28. Ishizaki H, Tsunoda T, Wada S, Yamauchi M, Shibuya M, Tahara H. Inhibition of tumor growth with antiangiogenic cancer vaccine using epitope peptides derived from human vascular endothelial growth factor receptor 1. Clin Cancer Res. 2006; 12:5841-9. https://doi.org/10.1158/1078-0432. CCR-06-0750.

29. Niethammer AG, Xiang R, Becker JC, Wodrich H, Pertl U, Karsten G, Eliceiri BP, Reisfeld RA. A DNA vaccine against VEGF receptor 2 prevents effective angiogenesis and inhibits tumor growth. Nat Med. 2002; 8:1369-75. https://doi.org/10.1038/nm794.

30. Wada S, Tsunoda T, Baba T, Primus FJ, Kuwano H, Shibuya $\mathrm{M}$, Tahara H. Rationale for antiangiogenic cancer therapy with vaccination using epitope peptides derived from human vascular endothelial growth factor receptor 2. Cancer Res. 2005; 65:4939-46. https://doi.org/10.1158/0008-5472. CAN-04-3759.

31. Andersen MH, Keikavoussi P, Brocker EB, SchulerThurner B, Jonassen M, Sondergaard I, Straten PT, Becker JC, Kampgen E. Induction of systemic CTL responses in melanoma patients by dendritic cell vaccination: cessation of CTL responses is associated with disease progression. Int J Cancer. 2001; 94:820-4. 
32. Germeau C, Ma W, Schiavetti F, Lurquin C, Henry E, Vigneron N, Brasseur F, Lethe B, De Plaen E, Velu T, Boon T, Coulie PG. High frequency of antitumor T cells in the blood of melanoma patients before and after vaccination with tumor antigens. J Exp Med. 2005; 201:241-8. https:// doi.org/10.1084/jem.20041379.

33. Mackensen A, Meidenbauer N, Vogl S, Laumer M, Berger J, Andreesen R. Phase I study of adoptive T-cell therapy using antigen-specific CD8+ T cells for the treatment of patients with metastatic melanoma. J Clin Oncol. 2006; 24:5060-9. https://doi.org/10.1200/JCO.2006.07.1100.

34. Gustafson MP, Knutson KL, Dietz AB. Therapeutic vaccines for malignant brain tumors. Biologics. 2008; 2:753-61.

35. Brat DJ, Bellail AC, Van Meir EG. The role of interleukin- 8 and its receptors in gliomagenesis and tumoral angiogenesis. Neuro Oncol. 2005; 7:122-33. https://doi.org/10.1215/ S1152851704001061.

36. Xie K. Interleukin- 8 and human cancer biology. Cytokine Growth Factor Rev. 2001; 12:375-91.

37. Okada H, Weller M, Huang R, Finocchiaro G, Gilbert MR, Wick W, Ellingson BM, Hashimoto N, Pollack IF, Brandes AA, Franceschi E, Herold-Mende C, Nayak $\mathrm{L}$, et al. Immunotherapy response assessment in neurooncology: a report of the RANO working group. Lancet Oncol. 2015; 16: e534-42. https://doi.org/10.1016/ S1470-2045(15)00088-1.

38. Yajima N, Yamanaka R, Mine T, Tsuchiya N, Homma J, Sano M, Kuramoto T, Obata Y, Komatsu N, Arima Y, Yamada A, Shigemori M, Itoh K, et al. Immunologic evaluation of personalized peptide vaccination for patients with advanced malignant glioma. Clin Cancer Res. 2005; 11:5900-11. https://doi.org/10.1158/1078-0432. CCR-05-0559.

39. Beal K, Abrey LE, Gutin PH. Antiangiogenic agents in the treatment of recurrent or newly diagnosed glioblastoma: analysis of single-agent and combined modality approaches. Radiat Oncol. 2011; 6:2. https://doi. org/10.1186/1748-717X-6-2.

40. Chinot OL, Wick W, Mason W, Henriksson R, Saran F, Nishikawa R, Carpentier AF, Hoang-Xuan K, Kavan P, Cernea D, Brandes AA, Hilton M, Abrey L, et al. Bevacizumab plus radiotherapy-temozolomide for newly diagnosed glioblastoma. N Engl J Med. 2014; 370:709-22. https://doi.org/10.1056/NEJMoa1308345.

41. Gilbert MR, Dignam JJ, Armstrong TS, Wefel JS, Blumenthal DT, Vogelbaum MA, Colman H, Chakravarti A, Pugh S, Won M, Jeraj R, Brown PD, Jaeckle KA, et al. A randomized trial of bevacizumab for newly diagnosed glioblastoma. N Engl J Med. 2014; 370:699-708. https:// doi.org/10.1056/NEJMoa1308573.

42. Friedman HS, Prados MD, Wen PY, Mikkelsen T, Schiff D, Abrey LE, Yung WK, Paleologos N, Nicholas MK, Jensen R, Vredenburgh J, Huang J, Zheng M, et al. Bevacizumab alone and in combination with irinotecan in recurrent glioblastoma. J Clin Oncol. 2009; 27:4733-40. https://doi. org/10.1200/JCO.2008.19.8721.

43. Nagane M, Nishikawa R, Narita Y, Kobayashi H, Takano S, Shinoura N, Aoki T, Sugiyama K, Kuratsu J, Muragaki Y, Sawamura Y, Matsutani M. Phase II study of single-agent bevacizumab in Japanese patients with recurrent malignant glioma. Jpn J Clin Oncol. 2012; 42:887-95. https://doi. org/10.1093/jjco/hys 121 .

44. Raizer JJ, Grimm S, Chamberlain MC, Nicholas MK, Chandler JP, Muro K, Dubner S, Rademaker AW, Renfrow $\mathrm{J}$, Bredel M. A phase 2 trial of single-agent bevacizumab given in an every-3-week schedule for patients with recurrent high-grade gliomas. Cancer. 2010; 116:5297-305. https://doi.org/10.1002/cncr.25462.

45. Field KM, Simes J, Nowak AK, Cher L, Wheeler H, Hovey EJ, Brown CS, Barnes EH, Sawkins K, Livingstone A, Freilich R, Phal PM, Fitt G, et al. Randomized phase 2 study of carboplatin and bevacizumab in recurrent glioblastoma. Neuro Oncol. 2015; 17:1504-13. https://doi.org/10.1093/ neuonc/nov104.

46. Sullivan LA, Brekken RA. The VEGF family in cancer and antibody-based strategies for their inhibition. MAbs. 2010; 2:165-75.

47. Plate KH, Breier G, Weich HA, Risau W. Vascular endothelial growth factor is a potential tumour angiogenesis factor in human gliomas in vivo. Nature. 1992; 359:845-8. https://doi.org/10.1038/359845a0.

48. Eisenhauer EA, Therasse P, Bogaerts J, Schwartz LH, Sargent D, Ford R, Dancey J, Arbuck S, Gwyther S, Mooney M, Rubinstein L, Shankar L, Dodd L, et al. New response evaluation criteria in solid tumours: revised RECIST guideline (version 1.1). Eur J Cancer. 2009; 45:228-47. https://doi.org/10.1016/j.ejca.2008.10.026.

49. Miyazawa M, Ohsawa R, Tsunoda $T$, Hirono S, Kawai M, Tani M, Nakamura Y, Yamaue H. Phase I clinical trial using peptide vaccine for human vascular endothelial growth factor receptor 2 in combination with gemcitabine for patients with advanced pancreatic cancer. Cancer Sci. 2010; 101:433-9. https://doi. org/10.1111/j.1349-7006.2009.01416.x.

50. Hirose Y, Aldape K, Takahashi M, Berger MS, Feuerstein BG. Tissue microdissection and degenerate oligonucleotide primed-polymerase chain reaction (DOP-PCR) is an effective method to analyze genetic aberrations in invasive tumors. J Mol Diagn. 2001; 3:62-7. https://doi.org/10.1016/ S1525-1578(10)60653-8.

51. Miwa T, Hirose Y, Sasaki H, Ezaki T, Yoshida K, Kawase T. Single-copy gain of chromosome 1q is a negative prognostic marker in pediatric nonependymal, nonpilocytic gliomas. Neurosurgery. 2011; 68:206-12. https://doi.org/10.1227/ NEU.0b013e3181fd2c2e.

52. Capper D, Zentgraf H, Balss J, Hartmann C, von Deimling A. Monoclonal antibody specific for IDH1 R132H mutation. Acta Neuropathol. 2009; 118:599-601. https:// doi.org/10.1007/s00401-009-0595-z. 